\title{
Oxidación de sulfuros en pizarra ornamental: tratamientos protectores con siloxanos
}

\section{Sulphide oxidation in ornamental slates: protective treatment with siloxanes}

\author{
${\underline{\text { T. } \operatorname{Rivas}^{(*)}}}$, J. Iglesias ${ }^{(*)}$, J. Taboada $(*)$, J. A.Vilán ${ }^{(*)}$
}

Recepción/Received: 19-VI-09

Aceptación/Accepted: 23-XI-09

Publicado online/Online publishing: 4-III-11

\section{RESUMEN}

En este trabajo se presentan los resultados de la medida de la eficacia de dos silanos-siloxanos aplicados en pizarras de techar con el objetivo de reducir la oxidación de las inclusiones de sulfuros de hierro. Los productos fueron aplicados por inmersión y spray a diferentes concentraciones. La efectividad de los tratamientos fue evaluada mediante la medida del ángulo de contacto estático y las variaciones del coeficiente de absorción de agua y su durabilidad mediante ciclos térmicos y de exposición a luz ultravioleta. A pesar del bajo consumo de ambos productos, debido al particular sistema poroso de estas rocas, y del bajo incremento del ángulo de contacto, ambos silanos-siloxanos incrementan notablemente la resistencia de los sulfuros a la oxidación durante los ciclos térmicos sin producir cambios relevantes en el color de la roca y muestran una aceptable durabilidad bajo la luz ultravioleta.

Palabras clave: pirrotina, oxidación de sulfuros, silanossiloxanos, pizarras, rocas ornamentales.

\section{SUMMARY}

In this work, we present the results of the measurement of the effectiveness of two silanes-siloxanes based products applied on roofing slates with the aim of slowing down the oxidation of the iron sulphide inclusions. The products were applied by immersion and spraying and also at different dilutions. The effectiveness of the treatments were evaluated by means of static contact angle measurements and water absorption coefficient variations; also, the durability under thermal cycles and the colour variations before treatment and before UVA exposition were tested. In all the cases, a very low product consumptions were obtained, due to the particular porous system of these rocks; also, any of the treatments increased the static angle. Nevertheless, the products tested remarkably increased the resistance of sulphides to the oxidation during thermal cycles without producing important changes in rock colour and also they have shown a good durability under UVA exposition.

Keywords: pyrrhotine, sulphide oxidation, silanes-siloxanes, slates, ornamental rocks.

(*) Universidad de Vigo (Vigo, España). 


\section{INTRODUCCIÓN}

La pizarra es una roca ornamental muy apreciada y de excelente comportamiento como material para techar debido a su excelente fisilidad y a la impermeabilidad de su estructura (1-3). Entre los caracteres que definen la calidad técnica-estética de la pizarra, la presencia de inclusiones minerales de pirita o pirrotina en la placa de techar es uno de los que más condicionan su salida al mercado (1-4), debido a su susceptibilidad a la oxidación por contacto con el oxígeno atmosférico o el agua. A través de este proceso, se generan alteraciones estructurales y huecos en la placa que disminuyen su resistencia mecánica, su durabilidad en obra y su carácter impermeable y modifican sensiblemente el aspecto de la pizarra, al generarse como producto de la alteración fases minerales de un elevado poder de tinción.

El estudio de los mecanismos de oxidación de minerales de sulfuro ha sido y es objeto de numerosos trabajos, tanto de enfoque teórico (5-7) como aplicado; entre éstos destacan aquellos enfocados a minimizar el riesgo de aguas ácidas, en los cuales se estudia la eficacia de distintos compuestos en frenar la oxidación de los sulfuros en condiciones de laboratorio (8-12). Aunque estos trabajos constituyen una excelente base de conocimiento para abordar la investigación de productos protectores de la corrosión de pizarra para techar, carecen de un enfoque aplicado orientado a optimizar procesos anticorrosivos de los sulfuros en las propias plantas de producción.

Por otra parte, el estudio de métodos de protección de pizarras contra la oxidación puede afrontarse desde la perspectiva de la conservación y protección de los materiales constructivos. La presencia de inclusiones inestables en los materiales rocosos usados en la construcción es considerada un problema grave de conservación (13). Teniendo en cuenta que la oxidación de estas inclusiones se produce en medio acuoso, y sin olvidar el papel que las bacterias ferrroxidantes tienen en el proceso, un posible tratamiento sería la aplicación en las planchas de productos protectores de carácter hidrofugante que reducirían la intensidad de los fenómenos de alteración en los que el agua es el agente alterante. La aplicación de hidrófugos es el tratamiento más habitual como protección de la roca en el patrimonio arquitectónico (14,15,16-21), pero mientras que son numerosísimos los estudios sobre eficacia y durabilidad de estos productos en rocas sedimentarias e ígneas, no existe ninguna referencia sobre la aplicación en rocas metamórficas como la pizarra.

En este trabajo se aborda por primera vez el estudio de la eficacia en pizarras ricas en sulfuros metálicos de productos hidrofugantes de tipo silano-siloxano habitualmente usados como protectores en el ámbito de la construcción arquitectónica. Su interés se justifica: 1) por la

\section{INTRODUCTION}

Slate is a highly appreciated ornamental rock, and its excellent fissility and impermeability mean that it makes excellent roofing material (1-3). Among the defining technical and aesthetic characteristics of slate is the presence of mineral inclusions of pyrite and pyrrhotite; these condition the value of the slate in the market (14), as they are susceptible to oxidation as a consequence of contact with atmospheric oxygen or water. The oxidation process leads to structural alterations and gaps in the slate that negatively affect its mechanical resistance, durability and impermeability properties; aesthetic appearance is also affected by the staining resulting from alterations in the minerals.

A number of studies have been made of sulphide oxidation mechanisms, whether from a theoretical (5-7) or practical perspective; among the latter are studies, aimed at minimizing the risk implied by acid rain, that assessed the effectiveness of different compounds in halting sulphide oxidation in laboratory conditions (812). Although these studies are an excellent knowledge base for tackling research into anti-corrosion agents for roofing slate, they are lacking in terms of an applied focus aimed at optimizing sulphide anti-corrosion processes in the production plant.

The study of anti-oxidation methods can also be tackled from the perspective of the conservation and protection of construction materials. The presence of unstable inclusions in rock used for construction purposes is considered to be a serious conservation problem (13). Bearing in mind that the oxidation of these inclusions occurs in aqueous environments, and not overlooking the role played by iron-oxidizing bacteria, a possible solution is the application of water-repellant protective agents that would reduce the intensity of the alterations caused by water. The application of water-repellant agents is the most common treatment for rock in architectural heritage monuments $(14,15,16-21)$. However, although there are many studies on the effectiveness and durability of these products when used on sedimentary and igneous rock., as far as we are aware, there has been no study conducted on applications to metamorphic rocks like slate.

We studied the effectiveness of silanes/siloxanes-based water-repellant products-habitually used as protective treatments for buildings and monuments-applied to slate rich in metallic sulphides. Our research was inspired, firstly, by the need to find a solution that 
necesidad de encontrar una solución que incremente la durabilidad de las pizarras con este problema y, por tanto, que permita el sostenimiento económico y de mercado de este recurso natural y 2 ) por el interés de conocer la eficacia de productos específicamente formulados como protectores de materiales pétreos cuando se aplican a pizarras, rocas de características muy peculiares.

Se han seleccionado dos pizarras actualmente en explotación y sobre ellas se han aplicado dos silanos-siloxanos comerciales mediante dos métodos, spray e inmersión, y a distintas concentraciones. Se ha evaluado la eficacia mediante la medida del ángulo de contacto estático, la capacidad de absorción de agua y la resistencia a ciclos térmicos, evaluándose además las modificaciones que los tratamientos ejercen en el color de las rocas. Además, se han sometido las pizarras tratadas a ciclos de exposición de luz ultravioleta, con el objeto de determinar tanto la durabilidad del tratamiento como cambios no deseados en el color derivado de la alteración de los silanos-siloxanos.

\section{MATERIAL Y MÉTODOS}

\subsection{Pizarras}

Para este estudio se han seleccionado dos pizarras que se explotan en la actualidad como material para techar y que frecuentemente han dado problemas de oxidación. El área donde afloran estas rocas se sitúa entre las provincias de Ourense y León, al noroeste de España, y geológicamente se enmarca en la Zona Asturoccidental-Leonesa establecida por (22), concretamente al dominio de Truchas (23, 24). En esta zona afloran las series pizarrosas del Ordovícico Medio-Superior situadas encima de la Cuarcita Armoricana, de las cuales tres unidades geológicas son aprovechadas para la extracción de pizarras ornamentales con aplicación para cubiertas de edificación. Estas tres formaciones con interés minero son las Pizarras de Luarca, la Formación Casaio y la Formación Rozadais (25). Las dos pizarras seleccionadas para este trabajo pertenecen a las Pizarras de Luarca (pizarra Luarca en este trabajo) y a la Formación Casaio (pizarra Casaio en este trabajo). En la Figura 1 se localizan en el contexto geológico de la zona.

Las dos pizarras se han caracterizado mineralógicamente por difracción de rayos X (Siemens D-5000) y petrográficamente mediante estudio de lámina delgada por microscopía petrográfica de secciones perpendiculares al plano de fisilidad. Se ha determinado la porosidad accesible al mercurio y la distribución porosimétrica mediante porosimetría de inyección de mercurio utilizando un porosímetro Pascal (Fisons Instruments) y utilizando piezas de las rocas de $1 \mathrm{~cm}^{3}$. La presión aplicada ha variado entre $0,1 \mathrm{kPa}$ y 400 $\mathrm{MPa}$, lo que permite caracterizar un rango amplio de dimensiones de radio de poro, entre 58.000 y $1,9 \mathrm{~nm}$. enhances the durability of slate rich in sulphides and so ensure the economic value in the market of this natural resource, and secondly, by an interest in establishing the effectiveness of products specifically formulated for petrous materials when applied to slate, a rock with very particular characteristics.

Applied to slate samples obtained from 2 quarries currently being exploited were 2 commercial silanessiloxanes compounds, at 2 different concentrations and using 2 methods (spray and immersion). Effectiveness was evaluated by measuring static contact angle, water absorption capacity and resistance to thermal cycles; also assessed was colour changes resulting from the treatments. Finally, the slate was cyclically exposed to ultraviolet light with a view to assessing both the durability of the treatment and non-desirable changes in colour resulting from silanes-siloxanes alterations.

\section{MATERIALS AND METHODS}

\subsection{Slates}

Selected for the purposes of this study was slate currently being exploited as roofing material that has frequently manifested oxidation problems. The slate outcrops are located in an area between the provinces of Ourense and Leon, in northwest Spain, geologically part of the West Asturian-Leonese zone (22) -specifically the Truchas domain $(23,24)$. The outcrops are slate series of the Middle-Upper Ordovician period located above Armorican quartzite. Three formations of mining interest are exploited for ornamental slate for use in roofing: Luarca, Casaio and Rozadais (25). The two slate types selected for our research are Luarca slate and Casaio slate. Figure 1 shows the geography and geology of the area.

The two slate types were mineralogically characterized using $x$-ray diffraction (Siemens D-5000) and petrographically characterized. For this, thin-sections cut perpendicularly to the fisility plane were studied using a petrographical microscope. Mercury injection porosimetry was used to determine pores accessible to mercury and pore distribution. This was carried out on rock specimens with a volume of around $1 \mathrm{~cm}^{3}$ using a Pascal Porosimeter from Fisons Instruments. Pressure was varied between $0.1 \mathrm{kPa}$ and 400 $\mathrm{MPa}$, which permitted a wide range of pore radius dimensions, from 58000 to $1.9 \mathrm{~nm}$, to be characterized. 


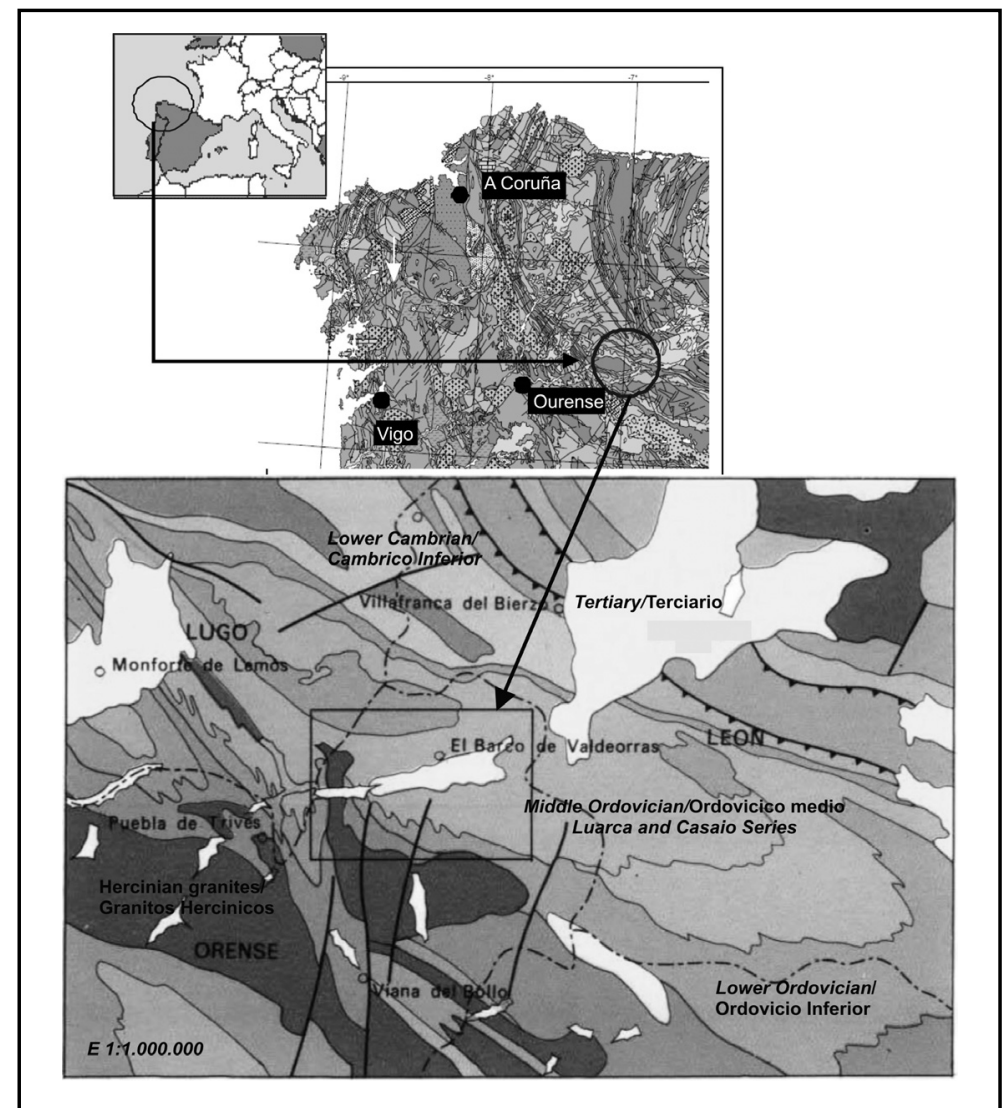

Figura 1. Localización geográfica y geológica de las pizarras Luarca y Casaio. Figure 1. Geography and geology of the Luarca and Casaio slates.

\subsection{Productos aplicados}

Se han seleccionado los productos comerciales de efecto hidrofugante Tegosivin $\mathrm{HL} 100 \AA$ ( $\mathrm{HL}$ en este trabajo) y Tegosivin HE328® (HE en este trabajo) ambos fabricados por Evonik Industries. HL es un metiletoxipolisiloxano en base solvente de densidad 1,14 gr/cc y HE es un alquilalcoxisilano/siloxano de densidad 0,96 gr/cc solvente en agua. Se han seleccionado ambos productos dada su elevada eficacia comprobada en otras rocas silicatadas en un trabajo previo (20).

Se han ensayado dos tipos de aplicación para los productos: por inmersión (I) y por spray (S). En la aplicación por inmersión, las planchas de pizarra, de dimensiones $300 \times 200 \times 4$ mm y cuya cara vista corresponde al plano de fisilidad, se introducen completamente en el producto durante 30 segundos, se dejan escurrir durante 10 segundos y se colocan verticalmente en bastidores hasta el secado completo. En el caso de la aplicación por spray se pulveriza el producto desde una distancia de 15 $\mathrm{cm}$ asegurando una cobertura completa de la superficie de la plancha mediante cuatro pasadas de spray en cada cara (que supone un tiempo de aplicación por superficie de 4 segundos). Tras la aplicación, se deja escurrir el

\subsection{Water-repellant products}

Two commercially available water-repellent products were used for this study, both manufactured by Evonik Industries: Tegosivin HL100尺 $(H L)$ and Tegosivin HE328 ${ }^{\circledR}$ (HE). HL is solvent-based methylethoxy polysiloxane with a density of $1.14 \mathrm{gr} / \mathrm{cc}$, whereas $\mathrm{HE}$ is water-based alkylalkoxysilane/siloxane with a density of $0.96 \mathrm{gr} / \mathrm{cc}$. These products were selected due to their high effectiveness as water-repellent in other types of silicate rocks checked in a previous work (20).

Two application methods-immersion (I) and spray (S) -were tested on slabs measuring $300 \times 200 \times 4 \mathrm{~mm}$ and cut parallel to fisility planes. In the immersion procedure, the slabs were immersed fully for 30 seconds and allowed to drip for 10 seconds, then were vertically positioned in a drying frame. In the spray procedure, both sides of the slate slabs were thoroughly sprayed 4 times from a distance of $15 \mathrm{~cm}$ for a total application time of 4 seconds per face, then were allowed to drip for 10 seconds before being positioned vertically in the drying frame. In both applications, drying speed was controlled by weighing the slabs after 2, 24 and 48 hours. Product consumption was calculated as weight 
producto sobrante durante 10 segundos y se colocan las planchas verticalmente en bastidores hasta su secado completo. En ambos tipos de aplicación, el control de la velocidad de secado se realizó mediante la medida del peso después de la aplicación y tras 2,24 y 48 horas. El consumo se calculó mediante las diferencias de peso de la plancha antes de tratar y después de tratar una vez alcanzado el peso constante y la materia seca polimerizada se calculó mediante la diferencia entre el peso sin tratar y tras el tratamiento una vez alcanzado el peso constante.

Los productos se han aplicado, además, en dos diluciones, siguiendo la recomendación del fabricante: al 5\% y al $10 \%(w / w)$. En el caso del HL se ha usado como solvente White Spirit y en el caso del HE, agua destilada. En total, teniendo en cuenta los dos tipos de aplicación y las dos diluciones, se han aplicado 8 tratamientos.

\subsection{Métodos para evaluar la eficacia y durabilidad}

La eficacia de los productos se ha determinado midiendo antes de tratar y a los 15 días de aplicar los tratamientos los siguientes parámetros:

- Ángulo de contacto estático siguiendo el método descrito (15). Se han usado 4 planchas por tratamiento, tomando en cada una de ellas los datos de ángulo de contacto de 15 microgotas distribuidas al azar sobre la cara vista.

- Coeficiente de absorción de agua (según 26), usando 5 planchas por cada tratamiento.

- Cambios en el aspecto de la roca mediante medidas colorimétricas. El color ha sido caracterizado con un espectrofotómetro Kónica-Minolta CM-700d equipado con CM-5100W SpectraMagic NX. Ver. 1.8 software y usando D65 como iluminante, $10^{\circ}$ observador y un diámetro de $3 \mathrm{~mm}$ y recogiendo los datos excluyendo el componente espectral. Usando 4 planchas por pizarra y tratamiento, se han tomado 15 medidas de color por plancha distribuidas al azar sobre la superficie de la cara vista, y obteniendo las medidas en las mismas planchas antes y después de los tratamientos. El espacio de color empleado fue el CIEL*a*b*(27), y en él la coordenada $\mathrm{L}$ representa la luminosidad, tomando valores desde 0 a 100 (negro al blanco respectivamente) y las coordenadas a* y b* expresan el Hue, tomando valores desde $+a$ (rojo) a -a (verde) y $+b$ (amarillo) $a$-b (azul). Asimismo, se han evaluado los cambios en el parámetro $\mathrm{C}^{*}{ }_{\mathrm{ab}}$, que representa el croma o saturación del color y se expresa mediante la ecuación $\mathrm{C}^{*}{ }_{\mathrm{ab}}=$ $\left((a)^{2}+(b)^{2}\right)^{1 / 2}$, y el Hue, que se expresa mediante la ecuación Hue $=\tan ^{-1}\left(a^{*} / b^{*}\right)$. Se ha calculado también el parámetro $\Delta \mathrm{E}$, expresado mediante $\Delta \mathrm{E}_{\mathrm{ab}}=\left(\Delta \mathrm{L}^{2}+\right.$ $\left.\Delta \mathrm{a}^{2}+\Delta \mathrm{b}^{2}\right)^{1 / 2}$, que permite evaluar de manera cuantitativa la magnitud de los cambios de color. differences before and after treatment (i.e. to constant weight) Polymerized dry matter was calculated as differences in weight before and after treatment.

The products were applied, following manufacturer's instructions, at 2 different concentrations: $5 \%$ and $10 \%$ $(w / w)$. The solvents used for HL and HE were White Spirit and distilled water, respectively. In total, each slate type underwent 8 treatments ( 2 products $x 2$ application methods $\times 2$ ).

\subsection{Effectiveness and durability evaluation}

In order to determine the effectiveness of the products, the following parameters were measured before treatment and 15 days after treatment:

- Static contact angle, (according to the method described in (15), using 4 slabs per treatment. Data was collected for the contact angle of 15 selected microdrops randomly distributed on the viewed face.

- Water absorption coefficient, (according to the method described in (26), using 5 slabs per treatment.

- Changes in rock by means colorimetric coordinates. Colour was characterized using a Konica-Minolta CM700d spectrophotometer equipped with CM-5100W SpectraMagic NX (Ver. 1.8) software, D65 illuminant, $10^{\circ}$ observer and target diameter $3 \mathrm{~mm}$. The data collected excluded the spectral component. Using 4 slabs representing each slate type and each treatment, 15 colour measurements were made, before and after treatment, of randomly selected points on each side of the slabs. The colour space used was CIEL*a*b* (27), with the $L$ coordinate representing luminosity (values between 0 and 100, representing black to white, respectively) and with the $a^{*}$ and $b^{*}$ coordinates representing the Hue (values from $+a$ for red to $-a$ for green, and from $+b$ for yellow to $-b$ for blue). Also evaluated were changes in $C^{*}{ }_{a b}$, representing chroma or colour saturation, expressed by the equation $C^{*}{ }_{a b}=\left((a)^{2}+\right.$ $\left.(b)^{2}\right)^{1 / 2}$, and Hue, expressed by the equation Hue = $\tan ^{-1}\left(a^{*} / b^{*}\right)$. The parameter $\Delta E$, expressed as $\Delta E_{a b}=\left(\Delta L^{2}+\Delta a^{2}+\Delta b^{2}\right)^{1 / 2}$, was also calculated to enable the magnitude of changes in colour to be evaluated quantitatively. 
La durabilidad de los tratamientos se ha evaluado sometiendo 5 planchas por tratamiento y pizarra al ensayo de ciclo térmico (según 26), tomando como control 5 probetas sin tratar. Paralelamente, otras cinco planchas de cada pizarra tratadas con cada tratamiento se han sometido a 1.320 horas de radiación UVA usando lámparas Osram Ultravitalux de radiación espectral máxima en UVA A y UVA B. Tras este ensayo se han repetido las medidas de color y del ángulo de contacto.

Con los datos de color y ángulo de contacto, un análisis estadístico ANOVA fue aplicado para detectar estadísticamente cambios significativos en ambos parámetros debidos a los tratamientos. Para cada tratamiento se ha aplcado un modelo cruzado considerando dos factores de variación: el factor tratamiento (con dos niveles, roca no tratada y roca tratada) y el factor probeta (con tantos niveles como probetas usadas para medir el color y el ángulo de contacto, es decir, cuatro). También se han tenido en cuenta en el análisis cruzado el factor concentración (dos niveles, concentración al $5 \%$ y al $10 \%$ ) y factor método de aplicación (con dos niveles, spray e inmersión).

Tras la aplicación de todos los tratamientos, se han observado muestra metalizadas en oro de ambas pizarras mediante microscopía electrónica de barrido, empleando un equipo Philips XL 30 con microanálisis EDX incorporado, y visualizando en modo electrones secundarios. Las muestras visualizadas corresponden a cortes frescos perpendiculares a las superficies tratadas, habiéndose observado tanto áreas filosilicatadas como inclusiones de sulfuros.

\section{RESULTADOS}

\subsection{CARACTERIZACIÓN DE LAS PIZARRAS}

En la Tabla 1 se presenta la composición modal de ambas pizarras, obtenida por estudio petrográfico de lámina delgada así como los valores de los parámetros físico-mecánicos determinados. Petrográficamente se describen como pizarras de tipo filita micácea con algo de cuarzo de bajo grado de metamorfismo regional; presentan una matriz filosilicatada en la que se observan cuarzo en microcristales, feldespato (del tipo microclina), glándulas de clorita y opacos asociados a los cristales de cuarzo. La foliación está señalada principalmente por la orientación de los cristales de micáceos así como de los agregados de cuarzo y clorita. Las dos variedades se diferencian en el tamaño de grano de los componentes minerales y en el hábito de las glándulas de clorita y de los opacos.

Mediante difracción de rayos $X$ se identifican en ambas pizarras las mismas fases minerales: cuarzo, microclina,
The durability of the treatments was evaluated by subjecting 5 slabs representing each slate type and treatment to a thermal cycle test, (according to the method described in (26), along with 5 untreated specimens as controls. In parallel, another 5 slabs representing each slate type and treatment underwent 1320 hours of UVA radiation using Osram Ultravitalux lamps with maximum UVA $A$ and UVA $B$ spectral radiation, following which, colour and contact angle measurements were repeated.

ANOVA was applied to the colour and contact angle data in order to detect statistically significant differences as a consequence of the treatments. For each treatment a crossed model was applied that considered 2 variation factors: the treatment factor (two levels, that is, treated and untreated rock) and the specimen factor (the 4 levels representing the 4 tests used to measure colour and contact angle). Also taken into account in the crossed analysis were the concentration factor (2 levels, that is, concentrations at 5\% and 10\%) and the application method factor (2 levels, immersion and spray).

Following application of all the treatments, gold metallized samples for both slate types were observed in a scanning electron microscope (Philips XL 30 with incorporated EDX microanalysis) in secondary electronSE mode. Fresh perpendicular surfaces to the treated surfaces were observed, both in phyllosilicated areas and sulphide-rich areas.

\section{RESULTS}

\subsection{SLATE CHARACTERIZATION}

Table 1 summarizes the composition of the Luarca and Casaio slates in terms of specific physical and mechanical parameters and data obtained in a petrographical thinsection study. Petrographically, the slates are described as micaceous phyllite with some low-grade quartz content and regional metamorphism; observed in the phyllosilicate matrix are quartz in microcrystals, microcline-type feldspar and chlorite glands and opaques associated with the quartz crystals. Foliation is signalled mainly by the orientation of the micaceous crystals and by the quartz and chlorite aggregates. The two slate types are differentiated by the grain size of the mineral components and by the chlorite glands and opaques.

$X$-ray diffraction confirmed the same mineral phases in both slate types: quartz, microcline, muscovite and 
Tabla 1 / Table 1

Pizarras Luarca y Casaio: composición modal en \% y propiedades físicas.

Luarca and Casaio slates: modal composition (\%) and physical properties.

\begin{tabular}{|c|c|c|}
\hline & Luarca & Casaio \\
\hline Composición modal (\%) / Modal composition (\%) & & 68 \\
\hline Matriz filosilicatada / Phyllosilicate matrix & 63 & 8 \\
\hline Clorita / Chlorite & 8 & 8.5 \\
\hline Cuarzo / Quartz & 5 & 7.5 \\
\hline Opacos / Opaques & 13 & 8 \\
\hline Feldespato (microclina) / Feldspar (microcline) & 10 & 2.69 \\
\hline Propiedades físicas / Physical properties & & 1.93 \\
\hline Densidad aparente (g/cm 3 / Apparent density (g/cm $\left.{ }^{3}\right)$ & 2.66 & 0.49 \\
\hline Porosidad total al Hg (\%) / Total porosity (Hg injection) (\%) & 1.87 & 47.17 \\
\hline Absorción de agua (\%) / Water absorption (\%) & 0.38 & \\
\hline
\end{tabular}

moscovita, clorita (clinocloro) como minerales esenciales y pirrotina como mineral accesorio. El análisis por difracción de rayos $X$ de las inclusiones de sulfuros indica que los agregados fusiformes son de pirrotina.

Ambas pizarras muestran porosidades accesibles al mercurio similares. La distribución de tamaños de poros obtenida por porosimetría de inyección de mercurio (Figura 2) muestra en ambas pizarras tres grupos de tamaño de poro: una región entre 10 y $100 \mu \mathrm{m}$, que presenta los valores de volumen poroso mayores, una segunda $y$ más estrecha región entre $0,1-0,01 \mu \mathrm{m}$ y una tercera más ancha que la anterior, de tamaños de poro intermedios. Teniendo en cuenta la mineralogía y textura de este tipo de rocas, el rango más ancho correspondería a los espacios vacíos entre planos de exfoliación, de naturaleza fisural y muy anchos y la región de poros más estrechos a las fisuras intergranulares de la matriz filosilicatada. Esas tres regiones de poros son diferentes en ambas pizarras: así, la pizarra tipo Casaio posee un menor volumen poroso en la región de tamaños de acceso más pequeños y un mayor volumen poroso en la región de tamaños intermedios. chlorite (clinoclore) as the essential minerals, and pyrrhotite as an accessory mineral. The $x$-ray diffraction study of the sulphide inclusions indicated that the fusiform aggregates were pyrrhotite.

Both slate types had similar porosities accessible to mercury. The distribution of pore sizes as obtained by mercury injection porosimetry (Figure 2) revealed 3 pore size groups in the 2 slate types: a region between 10 and $100 \mu \mathrm{m}$ with the largest pore volumes, a narrower region of between 0.1 and $0.01 \mu \mathrm{m}$, and a region with intermediate values. Bearing in mind the mineralogy and texture of this kind of rock, the widest region corresponds to empty spaces between the fissural and very wide exfoliation planes, and the narrower regions to intergranular fissures of the phyllosilicate matrix. These three regions were very different in the 2 slate types, with the Casaio slate having a smaller pore volume in the smaller access regions and a larger pore volume in the intermediate size regions compared to the Luarca slate.

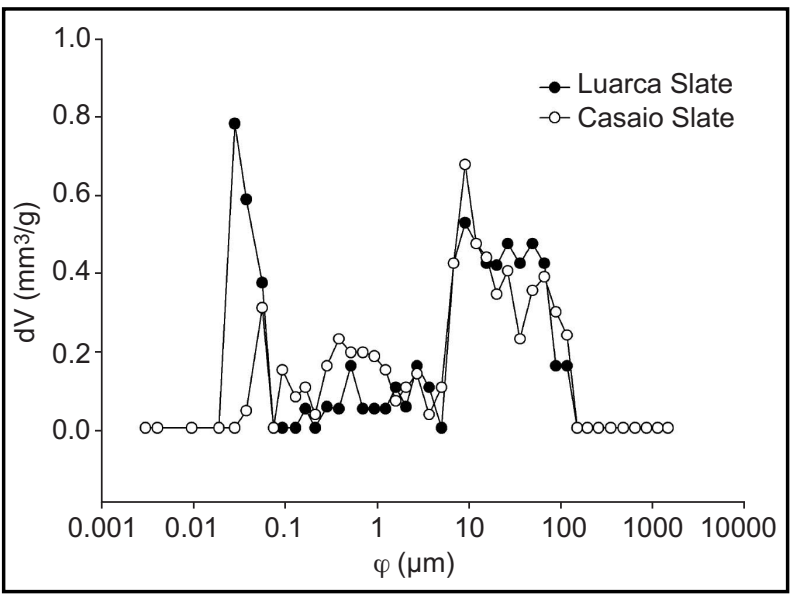

Figura 2. Distribución porosimétrica de ambas pizarras antes del tratamiento, obtenida mediante porosimetría de inyección de mercurio. Figure 2. Mercury porosimetric distribution of the Luarca and Casaio slates before treatment. 


\subsection{Consumo y eficacia de los tratamientos}

La Tabla 2 presenta los valores de consumo y materia seca correspondientes a cada tratamiento. El consumo obtenido es muy bajo y por debajo de los valores recomendados por los fabricantes para cada producto (en términos generales, se recomiendan consumos entre $200-1.500 \mathrm{gr} / \mathrm{m}^{2}$ ).

\subsection{Treatment consumption and effectiveness}

Table 2 provides consumption and dry matter values for each treatment. Consumption was very low, below even the values recommended by the manufacturer (200$\left.1500 \mathrm{gr} / \mathrm{m}^{2}\right)$.

Tabla 2 / Table 2

Consumo (en $\%$ y gr/m²) y materia seca (48 horas después de la aplicación, en \%) de los tratamientos aplicados, para cada dilución (5 y $10 \%$ ) y tipo de aplicación (I: inmersión; S: spray). HE: Tegosivin HE328. HL: Tegosivin HL100.

Consumption (\% and $\mathrm{gr} / \mathrm{m}^{2}$ ) and dry matter (48 hours after application) of treatments according to dilution (5 and 10\%) and application method (I: immersion; S: spray). HE: Tegosivin HE328. HL: Tegosivin HL100.

\begin{tabular}{|c|c|c|c|c|c|c|c|c|}
\hline \multirow{3}{*}{$\begin{array}{c}\text { Producto I } \\
\text { Product } \\
\text { (Tegosivin) }\end{array}$} & \multirow{3}{*}{$\begin{array}{c}\text { Dilución I } \\
\text { Dilution (\%) }\end{array}$} & \multirow{3}{*}{$\begin{array}{l}\text { Aplicación I } \\
\text { Application } \\
\text { Method }\end{array}$} & \multicolumn{3}{|c|}{ Luarca } & \multicolumn{3}{|c|}{ Casaio } \\
\hline & & & \multicolumn{2}{|c|}{ Consumo / Consumption } & \multirow{2}{*}{$\begin{array}{c}\text { Materia seca I } \\
\text { Dry matter }\end{array}$} & \multicolumn{2}{|c|}{ Consumo / Consumption } & \multirow{2}{*}{$\begin{array}{c}\text { Materia seca } / \\
\text { Dry matter }\end{array}$} \\
\hline & & & $\%$ & $\mathrm{gr} / \mathrm{m}^{2}$ & & $\%$ & $\mathrm{gr} / \mathrm{m}^{2}$ & \\
\hline HE328 & 5 & I & 0.81 & 90.72 & 0.01 & 0.66 & 73.92 & 0.023 \\
\hline HE328 & 5 & $\mathrm{~S}$ & 0.90 & 100.8 & 0.01 & 0.82 & 91.84 & 0.015 \\
\hline HE328 & 10 & I & 0.81 & 90.72 & 0.02 & 0.70 & 78.4 & 0.020 \\
\hline HE328 & 10 & $\mathrm{~S}$ & 0.85 & 95.2 & 0.01 & 0.70 & 78.4 & 0.021 \\
\hline HL100 & 5 & I & 0.60 & 67.2 & 0.01 & 0.60 & 67.2 & 0.020 \\
\hline HL100 & 5 & $\mathrm{~s}$ & 0.71 & 79.52 & 0.01 & 0.66 & 73.92 & 0.015 \\
\hline HL100 & 10 & I & 0.57 & 63.84 & 0.01 & 0.54 & 60.48 & 0.014 \\
\hline HL100 & 10 & $S$ & 0.83 & 92.96 & 0.03 & 0.67 & 75.04 & 0.022 \\
\hline
\end{tabular}

El bajo consumo podría indicar que el tiempo de inmersión no ha sido suficiente para absorber el producto hasta la cantidad recomendada. Para descartar esta posibilidad, se ha repetido la aplicación por inmersión durante 1 minuto, obteniéndose valores de consumo similares, lo que indica que un mayor tiempo de inmersión no supone una mayor absorción.

La cantidad de materia seca polimerizada es, en todos los casos, muy bajo. Comparando ambas pizarras, se constatan menores consumos en la pizarra tipo Casaio.

La Tabla 3 resume los resultados del ángulo de contacto y absorción de agua de las muestras antes y después de ser tratadas. Con respecto al ángulo de contacto, ningún tratamiento eleva el ángulo de contacto de las rocas por encima de $90^{\circ}$, mostrando por tanto todos ellos, con respecto a este parámetro, una nula eficacia. A pesar de que no alcanzan valores por encima de $90^{\circ}$, los tratamientos reducen la capacidad hidrofílica de las rocas, ya que las diferencias entre los valores de ángulo antes y después todos los tratamientos son estadísticamente significativos, indicando el ANOVA que la variación se atribuye al efecto o factor tratamiento. Este mismo análisis muestra que el factor probeta es significativo, lo que indica una importante variabilidad de una probeta a otra en la medida del ángulo de contacto. También, se obtiene significación en la interacción entre ambos factores, lo que revela que las distintas probetas muestran respuestas diferentes frente al mismo tratamiento.
Given that the low consumption may be due to insufficient immersion time, the immersion experiment was repeated for 1 minute. However, very similar consumption values were obtained, which indicates that longer immersion does not mean greater absorption.

The quantity of polymerized dry matter was also very low. Comparing both slate types, consumption was lower for the Casaio slate.

Table 3 summarizes contact angle and water absorption results for the samples before and after treatment. With regard to the contact angle, in no treatment was this angle above $90^{\circ}$, revealing, therefore, null effectiveness for this parameter for all the treatments. Nonetheless, the treatments did reduce the hydrophilic behaviour of the rocks; the differences between contact angles before and after treatment were statistically significant, with the ANOVA indicating that the variation was attributable to the treatment factor. This analysis also showed that the specimen factor was significant, indicating important variability from one specimen to another in contact angle measurements. Also significant was the interaction between the treatment and specimen factors, revealing that the different specimens responded differently to the same treatment. 
Tabla 3 / Table 3

Valores de ángulo de contacto estático (en grados) y porcentaje de absorción de agua (en \%) antes y después de los tratamientos, para cada dilución (5 y 10\%) y modo de aplicación (I: inmersión; S: Spray). Se muestran también los valores de DE*ab obtenidos con las diferencias entre los valores de antes y después de tratar y entre los valores de las muestras tratadas y los de las muestras sometidas con posterioridad a radiación UVA. HE: Tegosivin HE328. HL: Tegosivin HL100.

Contact angles (grades) and water absortion (\%) before and after treatment with silane-siloxanes for every dilution (5 and $10 \%)$ and application method (I: immersion; S: spray). There are also shown DE*ab values obtained with the differences between values before and after treatments. In addition, the differences between treated samples and post-U.V.A exposure samples are shown. HE: Tegosivin HE328. HL: Tegosivin HL100.

\begin{tabular}{|c|c|c|c|c|c|c|c|}
\hline \multirow{2}{*}{$\begin{array}{l}\text { Producto I } \\
\text { Product } \\
\text { (Tegosivin) }\end{array}$} & \multirow{2}{*}{$\begin{array}{c}\text { Dilución I } \\
\text { Dilution (\%) }\end{array}$} & \multirow{2}{*}{$\begin{array}{l}\text { Aplicación I } \\
\text { Application } \\
\text { Method }\end{array}$} & \multicolumn{2}{|c|}{$\begin{array}{l}\text { Ángulo de contacto / } \\
\text { Contact angle }\left({ }^{\circ}\right)\end{array}$} & \multirow{2}{*}{$\begin{array}{l}\text { Absorción de } \\
\text { agua / Water } \\
\text { absorption (\%) }\end{array}$} & \multicolumn{2}{|c|}{$\Delta \mathrm{E}^{*}{ }_{\mathrm{ab}}$} \\
\hline & & & \begin{tabular}{|c|} 
Antes de tratar $I$ \\
Pre-Treatment
\end{tabular} & $\begin{array}{c}\text { Después de } \\
\text { tratar } / \\
\text { Post-Treatment }\end{array}$ & & Pre-UVA & Post-UVA \\
\hline \multicolumn{8}{|c|}{ Luarca } \\
\hline HE328 & 5 & I & 22.26 & 80.02 & 0.25 & 3.61 & 0.08 \\
\hline HE328 & 5 & $S$ & 23.43 & 80.21 & 0.24 & 3.4 & 0.1 \\
\hline HE328 & 10 & I & 20.42 & 80.14 & 0.23 & 5.73 & 0.17 \\
\hline HE328 & 10 & $S$ & 19.55 & 80.25 & 0.22 & 5.03 & 0.2 \\
\hline HL100 & 5 & I & 19.96 & 78.66 & 0.21 & 4.94 & 0.06 \\
\hline HL100 & 5 & $S$ & 20.99 & 80.37 & 0.22 & 4.81 & 0.05 \\
\hline HL100 & 10 & I & 22.09 & 78.02 & 0.22 & 5.74 & 0.06 \\
\hline HL100 & 10 & $S$ & 27.27 & 78.6 & 0.21 & 5.92 & 0.07 \\
\hline $\begin{array}{l}\text { Sin tratar } \\
\text { /Untreated }\end{array}$ & - & - & - & - & 0.38 & - & - \\
\hline \multicolumn{8}{|c|}{ Casaio } \\
\hline HE328 & 5 & I & 38.25 & 83.7 & 0.24 & 4.69 & 0.3 \\
\hline HE328 & 5 & $S$ & 28.01 & 83.49 & 0.36 & 4.29 & 0.36 \\
\hline HE328 & 10 & I & 36.36 & 84.82 & 0.24 & 6.11 & 0.2 \\
\hline HE328 & 10 & $S$ & 37.16 & 83.75 & 0.18 & 6.26 & 0.09 \\
\hline HL100 & 5 & I & 35.69 & 81.17 & 0.23 & 5.11 & 0.27 \\
\hline HL100 & 5 & $S$ & 43.39 & 81.64 & 0.21 & 5.38 & 0.33 \\
\hline HL100 & 10 & I & 38.27 & 81.91 & 0.2 & 6.35 & 0.21 \\
\hline HL100 & 10 & $\mathrm{~S}$ & 41.51 & 81.46 & 0.2 & 6.73 & 0.25 \\
\hline $\begin{array}{l}\text { Sin tratar } \\
\text { Untreated }\end{array}$ & - & - & - & - & 0.41 & - & - \\
\hline
\end{tabular}

No se observan diferencias entre los valores de ángulo de contacto en función de la concentración y del tipo de aplicación, aunque el análisis de varianza revela únicamente en la pizarra Luarca tras el tratamiento con $\mathrm{HL}$ diferencias significativas atribuibles tanto a la concentración como al método de aplicación.

Con respecto al ensayo de absorción de agua, sí se observa en la Tabla 3 que tras la aplicación de los productos se produce una importante disminución de la capacidad de absorción de agua. En ambas pizarras, este parámetro parece sufrir una mayor disminución tras el tratamiento con HL.

Por microscopía electrónica se puso en evidencia que ambos productos forman una capa sobre la superficie de la pizarra en forma de película continua y nítidamente diferenciada de la roca (Figura 3). La existencia de esta misma película se constata sobre las inclusiones de sulfuro, lo que demuestra que los sulfuros de estas pizarras poseen reactividad química frente a los silanos-siloxanos.
No differences were observed between contact angle values according to concentration and application method, although the ANOVA revealed significant differences attributable to both concentration and application method in the Luarca slate after $\mathrm{HL}$ treatment.

As for the water absorption test (Table 3), application of the products produced a significant reduction in water absorption capacity. In both slate types, this reduction appeared to be greater for the HL treatment.

The electron microscope clearly showed that both products layered the surface of the slate with a continuous film that could be clearly differentiated from the rock (Figure 3). The existence of this film was also evident in the sulphide inclusions, demonstrating that the sulphides in these slates chemically react to silanes/siloxanes. 


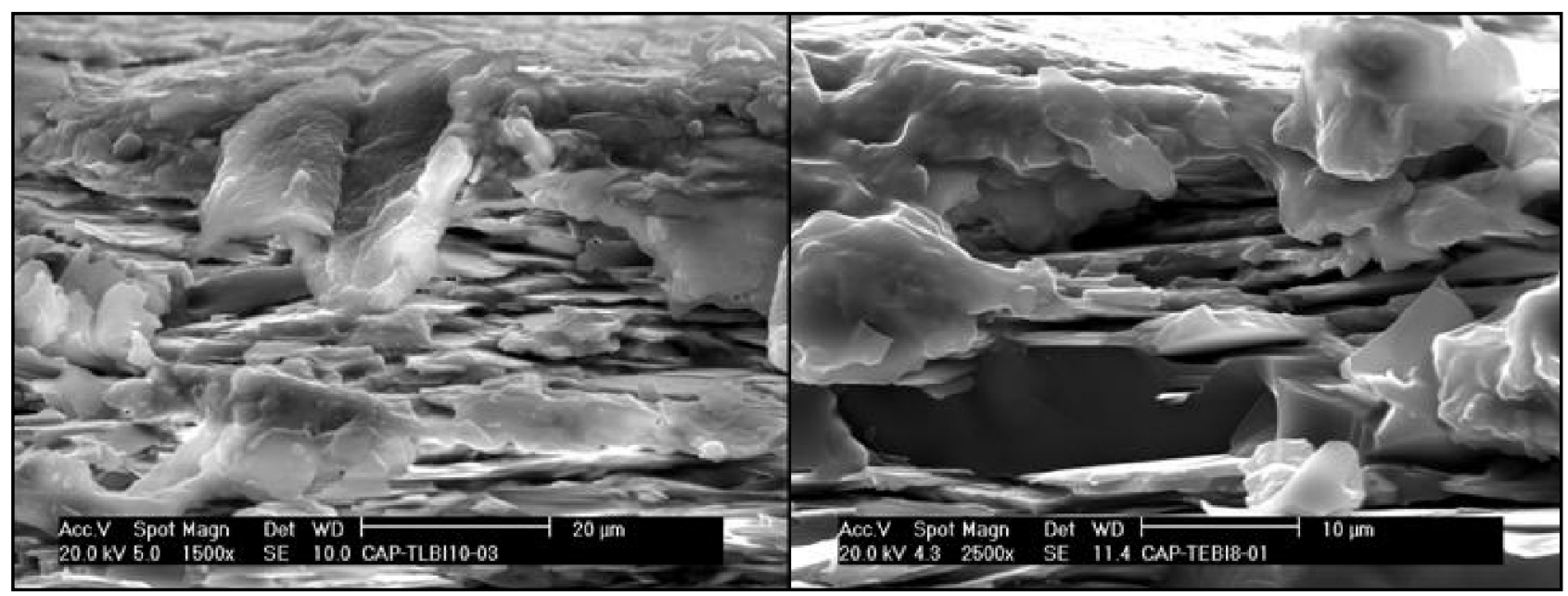

Figura 3. Microfotografías tomadas al microscopio electrónico de la pizarra Casaio tratadas con Tegosivin HL (izquierda) y Tegosivin HE (derecha) por inmersión al $10 \%$ donde se observa el film superficial continuo que forman ambos productos sobre la superficie de la pizarra.

Figure 3. Electron microscope microphotographs of the Casaio slate after immersion in 10\% Tegosivin HL100 (left) and $10 \%$ Tegosivin HE328 (right), showing the continuous surface film formed by both products on the slate.

El ensayo de ciclos térmicos permitió comprobar que, a pesar del bajo incremento en los valores de ángulo de contacto tras los tratamientos, la presencia de éstos en las rocas ralentiza el proceso de oxidación de las inclusiones de sulfuros, y lo hacen de manera similar en ambas pizarras. Las pizarras sin tratar comenzaron a mostrar síntomas de oxidación de los sulfuros a los 10 ciclos, mientras que las pizarras tratadas no mostraron síntomas de deterioro hasta pasados 18 . Se ha observado, además, una diferente eficacia de cada tratamiento en la capacidad de protección frente a la oxidación. Así, en la pizarra Luarca, el tratamiento más eficaz ha resultado ser $\mathrm{HL}$ al $10 \%$ aplicado mediante inmersión. En las imágenes de la Figura 4, que corresponden al aspecto de las inclusiones finalizado el ensayo (tras 20 ciclos), se puede observar que tras estos tratamientos las inclusiones de sulfuros tratadas con este producto se presentan intactas. El resto de los tratamientos no ejercen la misma protección ya que, tras el mismo número de ciclos, las inclusiones de sus planchas correspondientes mostraban signos de oxidación, si bien muy ligeros. En la pizarra tipo Casaio, ambos productos, $\mathrm{HL}$ y $\mathrm{HE}$, mostraron la misma eficacia siendo ésta mayor cuando se aplicaron al $10 \%$ : tras 20 ciclos, no se observó en ninguna de las planchas tratadas con estos productos ningún signo de oxidación.

Con respecto a los cambios en el aspecto de las rocas tras los tratamientos, los cambios en las coordenadas colorimétricas se presentan gráficamente en la Figura 5. Se observa que la dirección de los cambios producidos en las coordenadas medidas es similar en ambas pizarras tras los tratamientos: el descenso en la coordenada $\mathrm{L}$ acompañado del descenso en el parámetro $\mathrm{C}^{*}{ }_{\mathrm{ab}}$ indica un oscurecimiento del color. No se observan, sin embargo,
The thermal cycle test showed that, despite the small increase in contact angle values after treatment, the presence of the siloxanes in the rock slowed down oxidation of the sulphide inclusions, and to a similar degree in both slate types. The untreated slate samples began to show signs of sulphide oxidation after 10 cycles, whereas the treated slate samples showed no signs of deterioration until after 18 cycles. Observed also was different product effectiveness in terms of antioxidation capacity. Thus, for the Luarca slate, the most effective treatment was $10 \% \mathrm{HL}$ applied via immersion. The images in Figure 4, showing the inclusions after completing the test (after 20 cycles), reveal the sulphide inclusions to be intact. The other treatments were not as effective, with the inclusions showing slight signs of oxidation after the same number of cycles. For the Casaio slate, both HL and HE were equally effective, and especially at 10\%: after 20 cycles, no signs of oxidation were observed in any of the slabs treated with these products.

As to changes in the appearance of the slate following the treatments, changes in the colorimetric coordinates are shown in Figure 5. It can be observed that the direction of the changes in the coordinates was similar for both slate types after treatment: the fall in the $L$ parameter accompanied by a fall in the $C^{*}{ }_{a b}$ parameter indicates a darkening in colour. No changes in hue were observed, however. Figure 5 shows that the angle did 

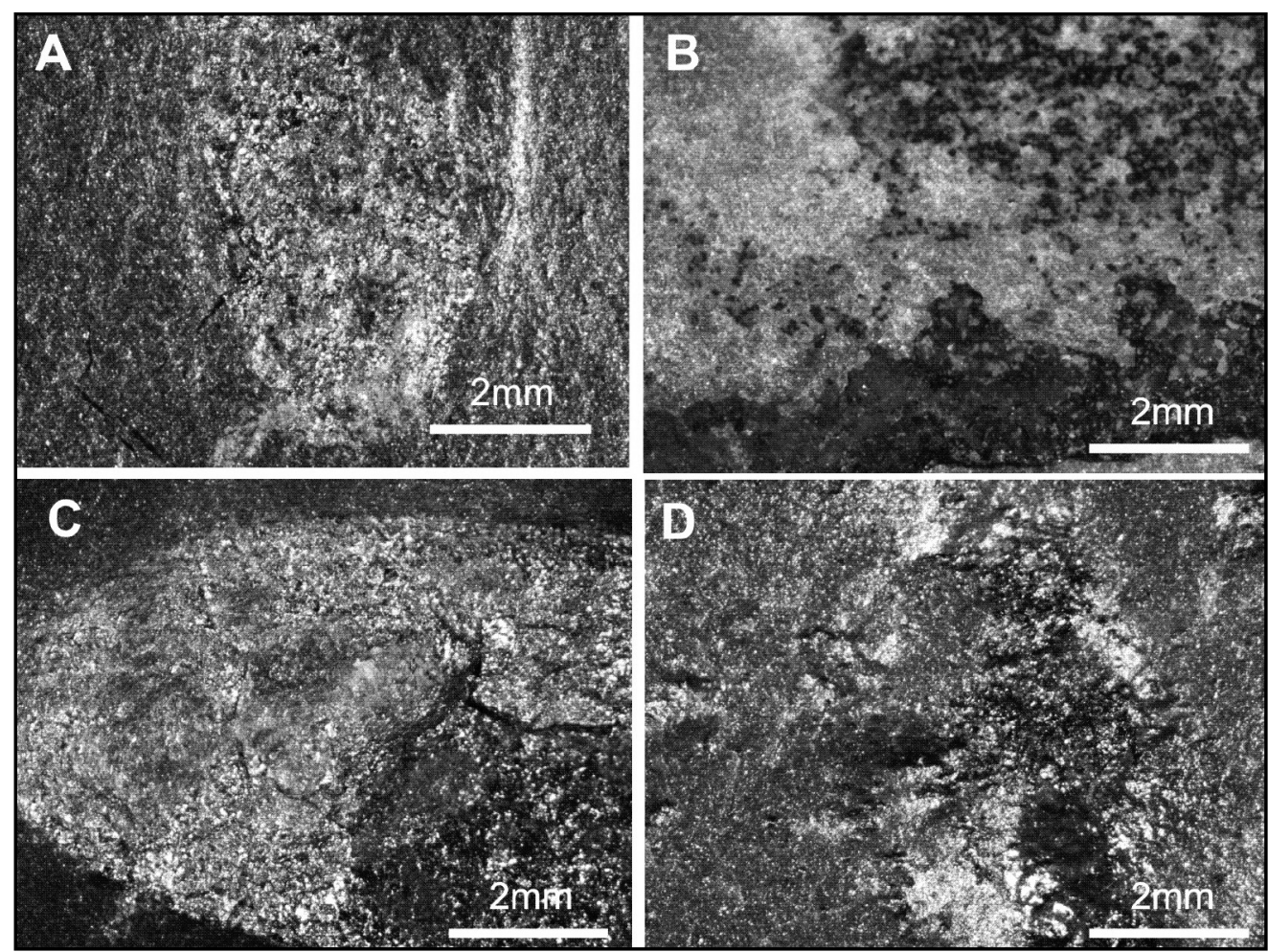

Figura 4. Aspecto de las inclusiones de sulfuros metálicos tras 20 ciclos del ensayo de ciclos térmicos de muestras de las pizarra sin tratar y no sometida al ensayo de ciclos térmicos $(A)$, sin tratar y sometida al ensayo de ciclos térmicos $(B)$ y tratadas con los productos Tegosivin HE 328 (C) y Tegosivin HL 100 (D) y sometidas al ensayo.

Figure 4. Appearance of the metallic sulphide inclusions: $(A)$ untreated slate which did not undergo thermal cycles, $(B)$ untreated slate after 20 thermal cycles, (C) slate treated with Tegosivin HE328 after 20 thermal cycles, and (D) slate treated with Tegosivin HL100 after 20 thermal cycles.

cambios en el Hue: en la Figura 5 se muestra que el ángulo métrico no cambia mientras que sí lo hace el croma métrico, indicando una reducción de la saturación del color que tiende hacia términos neutros-grises. Según los valores de $\Delta \mathrm{E}$, presentados en la Tabla 3, el cambio de color es comparativamente más elevado en la pizarra Casaio que en la Luarca, y en ambas pizarras, los cambios son mayores para el $\mathrm{HL}$ y para las concentraciones más altas de aplicación de ambos productos. Aunque el $\Delta \mathrm{E}$ es más elevado tras la aplicación de $\mathrm{HL}$, la observación de las piezas permitió constatar que sobre las planchas tratadas con la formulación en base agua (HE) permanecían residuos blanquecinos tras el secado apreciables a simple vista, efecto que no se observó en las planchas tratadas con HL. El ANOVA factorial realizado con la totalidad de los datos de las coordenadas colorimétricas revela que los valores de todas las coordenadas medidas son significativamente diferentes antes y después de los tratamientos; esto ocurre en las dos pizarras. El mismo análisis revela que en la mayoría de los casos se encuentran variaciones significativas en todas las coordenadas medidas atribuibles al factor probeta y, también en muchos casos, se encuentra que la interacción entre ambos factores es significativa. not change, unlike the chroma, indicating a reduction in colour saturation and a tendency towards neutral-grey tones. Values for $\Delta E$ are presented in Table 3. The change in colour was comparatively higher in the Casaio slate than in the Luarca slate, and the changes in both slate types were greater for $H L$ and for the highest concentrations of both products. Although $\Delta E$ is higher after HL application, it should be notice that after HE application, whitish residues were observed on the surfaces of both slates; this fact was not observed for $\mathrm{HL}$ product. Factorial ANOVA performed with all the colorimetric coordinate data revealed that the values for the measured coordinates were significantly different after treatment, and for both slate types. The same analysis revealed that, in most cases, there were significant variations in all the measured coordinates that were attributable to the specimen factor, and also that, in many cases, the interaction between the treatment and specimen factors was significant. 

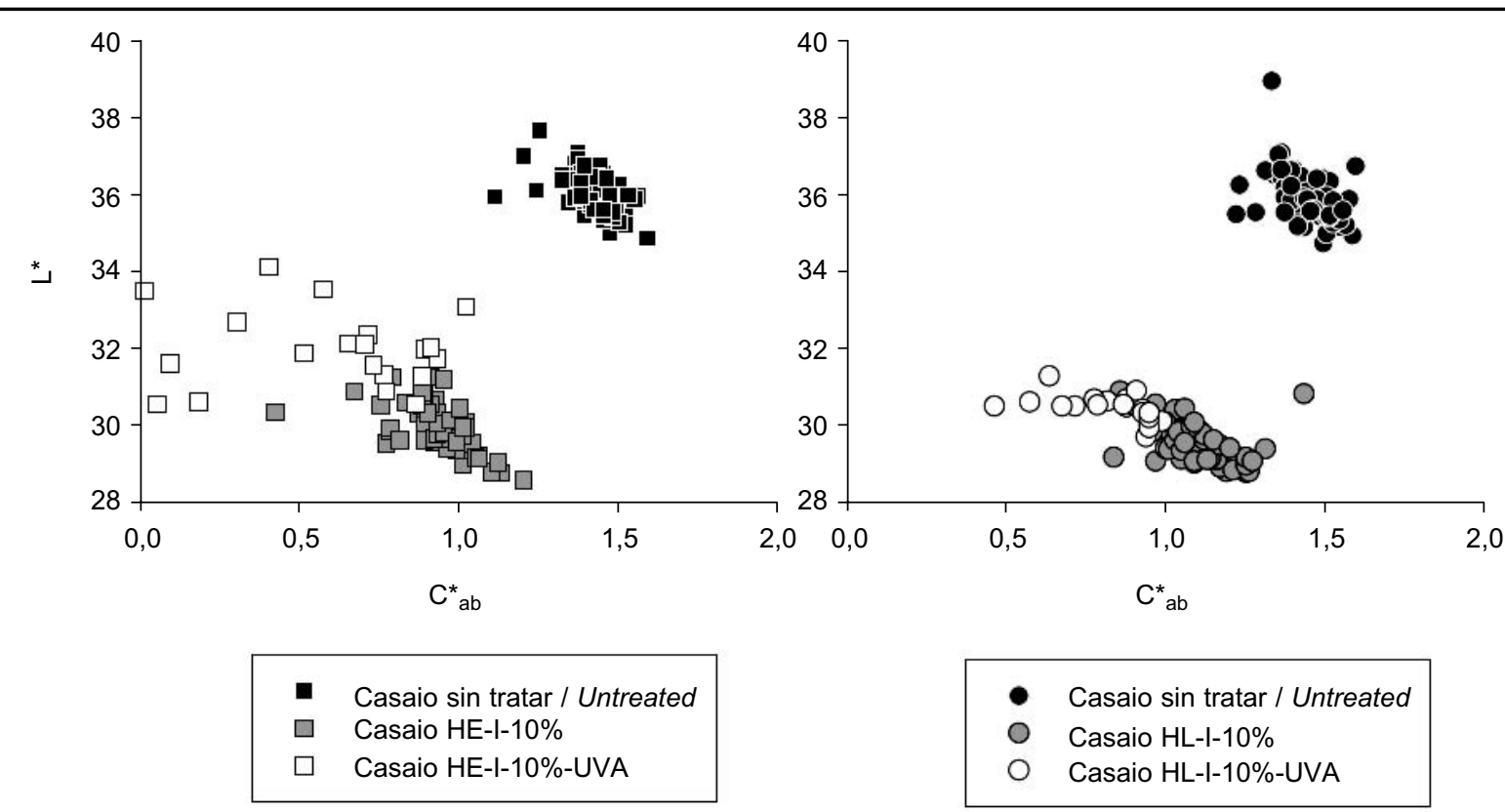

$a^{*}$
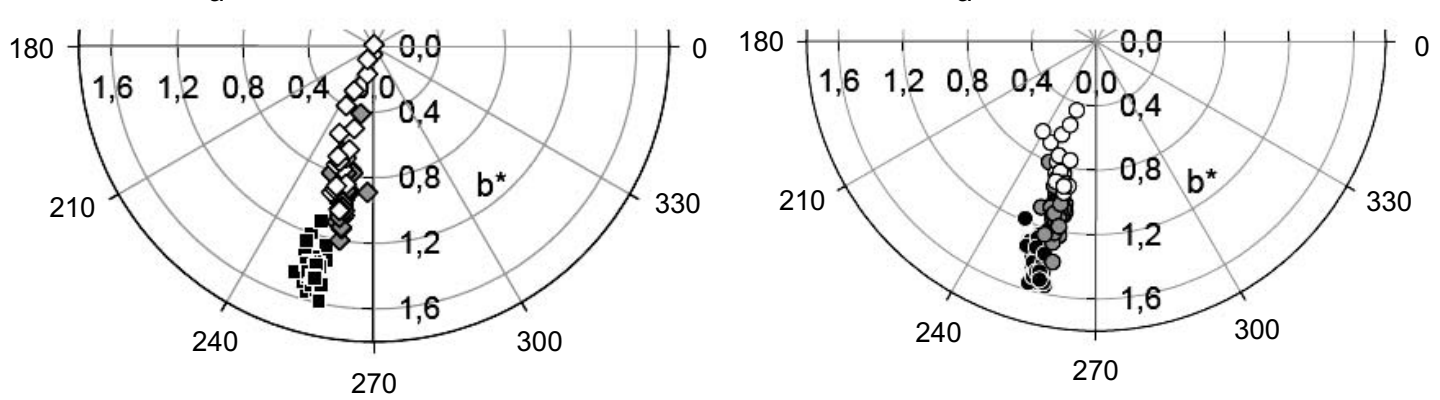

Figura 5. Gráficos comparativos $L^{*}-C^{*} a_{b}$ y gráficos polares $a^{*}-b^{*}$ de los valores de las coordenadas colorimétricas de la pizarra Casaio antes y después de tratar por inmersión con Tegosivin HE y Tegosivin HL al 10\% (HE-I-10\% y HL-I-10\%) y después de tratar y tras la exposición a la radiación ultravioleta (HE-I-10\%-UVA y HL-I-10\%-UVA).

Figure 5. Comparative $L^{*}-C^{*}{ }_{a b}$ graphs and $a^{*}-b^{*}$ polar graphs for the colorimetric coordinate values for Casaio slate before and after treatment by immersion with Tegosivin HE328 and Tegosivin HL100 at 10\% (HE-I-10\% and HL-I-10\%)) and after treatment and eexposure to ultraviolet radiation (HE-I-10\%-UVA y HL-I-10\%-UVA).

Tras el ensayo de alteración por rayos UVA, las medidas de ángulo de contacto no han sufrido variaciones destacables; sin embargo, las variaciones encontradas en las coordenadas colorimétricas revelan que la exposición a radiación ultravioleta provoca cambios en los silanossiloxanos: en la Figura 5 se observa que tras la exposición se produce un ligero incremento en la luminosidad pero acompañado de un descenso en el croma; éste descenso se aprecia con más claridad en los gráficos polares $a *-b *$ en donde se observa que la nube de puntos correspondientes a los valores tras la exposición se acercan todavía más hacia los grises. De todas formas, estos cambios son muy pequeños, teniendo en cuenta los valores de $\Delta \mathrm{E}$ expresados en la Tabla 3, muy bajos (no superan valores de $\Delta E$ superiores a 0,5 ) comparativamente a los mismos valores correspondientes a la roca
Contact angle values did not change to any significant degree after UVA ray exposure; nonetheless, variations in the colorimetric coordinates reveal that the exposure to ultraviolet radiation caused changes in the silanes/siloxanes. Figure 5 shows that there was a slight increase in luminosity accompanied by a fall in the chroma parameter after exposure. This fall was more visible in the $a^{*}-b^{*}$ polar graphs, where it can be observed that the points corresponding to the post-exposure values approaches the grey tones even more. Nonetheless, these changes were very small, bearing in mind the $\Delta E$ values in Table 3, which are very low (no $\Delta E$ values above 0.5 ) in comparison with the corresponding values for treated slate unaltered by UVA radiation. The same table also shows that variations following exposure were 
tratada pero sin alterar con radiación UVA. En esta tabla se observa también que las variaciones tras la exposición son menores en la pizarra tipo Luarca y en ambas para el Tegosivin HL.

\section{DISCUSIÓN}

Los productos ensayados muestran un consumo muy bajo en las pizarras estudiadas y una nula eficacia medida mediante el ángulo de contacto estático. Sin embargo, el ensayo de resistencia a los ciclos térmicos indica que a pesar de estos hechos, los tratamientos aplicados muestran una elevada capacidad de protección frente a la oxidación de los sulfuros metálicos.

Con respecto al consumo y materia seca, y habiendo constatado que mayores tiempos de aplicación no conllevan mayores consumos, se puede concluir que en la absorción de los productos pueden influir aspectos directamente relacionados con la textura de las pizarras, especialmente con la porosidad, la distribución porosimétrica y el tipo de fisuración predominante. Esta relación ya se había constatado en otros tipos rocosos, como los granitos y calizas $(14,15,16-20)$, pero en las pizarras se suma el hecho de poseer una particular configuración del espacio poroso: las pizarras de este estudio presentan una porosidad de acceso ancho, que correspondería a las fisuras asociadas a los planos fisurales que confieren la fisilidad, y una porosidad de acceso medio y pequeño que correspondería a las fisuras intergranulares; la textura afanítica de las pizarras conlleva que la comunicación entre estos poros de menor tamaño sea muy reducida, de ahí el carácter impermeable de estas rocas; teniendo en cuenta la estructura muy orientada de la roca es previsible también que la comunicación entre estos espacios de pequeño tamaño y los planos fisurales más anchos sea muy poco eficaz. Estos hechos explicarían el bajo consumo de los tratamientos, incluso con porosidades totales no demasiado bajas como es el caso; hay que tener en cuenta además que durante la aplicación del producto, la porosidad que está mayoritariamente involucrada (las planchas están cortadas aprovechando los planos de fisilidad) es aquella de acceso más estrecho y menos accesible.

Los bajos valores de ángulo de contacto obtenidos tras el tratamiento indicarían una nula eficacia, lo que podría relacionarse con los bajos valores de consumo y materia seca. Sin embargo, de la bibliografía al respecto sobre otros tipos rocosos no se deduce la relación directa entre consumo y eficacia: estos mismos productos, aplicados en rocas calizas, muestran eficacias nulas incluso con consumos adecuados (19) y en granitos, los mismos productos muestran sin embargo eficacias muy satisfactorias con consumos que no alcanzan los valores recomendados smaller for the Luarca slate, and also for HL for both slate types.

\section{DISCUSSION}

The tests show low product consumption by the slate types studied and null effectiveness as measured by the static contact angle. Nonetheless, the test for resistance to thermal cycles shows that the treatments have a high capacity for protecting the slate against metallic sulphide oxidation.

With regard to consumption and dry matter, and given that application time does not result in greater consumption, it can be concluded that product absorption may be influenced by the texture of the slate, especially by porosity, pore distribution and the predominant type of fissuration. This relationship has been demonstrated for other rock types such as granites and limestones (14, 15, 16-20); in slate, however, an additional factor is the particular configuration of the porous spaces. The Casaio and Luarca slates used in our study have wide access porosity corresponding to the fissures associated with the fissural planes that produce fissility, and medium and narrow access porosity corresponding to intergranular fissures. The aphanitic texture of slate makes for reduced communication between these smaller pores, thus explaining the impermeability. Bearing in mind the very oriented structure of the rock, it is also possible that there is poor communication between these small spaces and the wider fissural planes. These facts would explain the low consumption of the treatments, even with total porosities that were not excessively low. It should be borne in mind also that the narrower and less accessible pores are most implicated during product application (the slate slabs are cut along the fissility planes).

The low contact angle values after treatment would indicate null effectiveness, and this may be related to the low consumption and dry matter values. Nonetheless, the literature referring to other types of rock makes no reference to a direct relationship between consumption and effectiveness: the same products applied to limestone showed null effectiveness even with a suitable level of consumption (19), whereas in granites, effectiveness was satisfactory for consumptions that were below the recommended values (15). Effectiveness 
(15). Es indudable que también en la eficacia deben influir parámetros intrínsecos que determinan la reactividad del sustrato a los tratamientos, el mecanismo de polimerización de los productos y, por tanto, en la eficacia final. Por otra parte, hay que tener en cuenta que en la bibliografía antes citada y en el presente trabajo se mide el ángulo de contacto estático, el cual, según algunos autores (21), puede dar lugar a dificultades en la interpretación de la eficacia de un tratamiento de protección, siendo más apropiado utilizar el ángulo de retroceso para medir la eficacia.

A pesar de estos hechos, es indudable que ambos productos son eficaces en cuanto a que reducen casi a la mitad la capacidad de absorción de agua y ralentizan la oxidación durante los ciclos térmicos. Por tanto, la película superficial formada sobre las inclusiones de pirrotina parece ser suficientemente eficaz como protectora frente a la oxidación del mineral. En este sentido, de los dos silanos-siloxanos evaluados, parece más indicado como protector frente a la oxidación el Tegosivin HL100 ya que la formulación solvente en agua, el Tegosivin HE328, deja residuos apreciables en las planchas. Quedaría por tanto dirigir la investigación hacia la definición del protocolo de aplicación industrial, en el cual, el proceso clave a definir afectaría a la fase posterior a la inmersión, buscando el procedimiento que permita el secado de las planchas sin comprometer la velocidad de producción.

Paralelamente, es interesante abordar el estudio de la eficacia de otros productos formulados específicamente para frenar la oxidación de los sulfuros y que han dado resultados prometedores en laboratorio $(11,12)$. Estos estudios deberán desarrollarse con el objetivo de adaptar su aplicación a una escala industrial: esto obliga a aplicarlos a planchas de pizarra de dimensiones comerciales y, por tanto, evaluar no sólo su eficacia como protectores, sino también los efectos nocivos sobre la pizarra, principalmente en el color.

\section{CONCLUSIONES}

Los resultados del estudio permiten afirmar que el silanosiloxano comercial Tegosivin HL puede ser utilizado para ralentizar la velocidad de oxidación de los sulfuros metálicos en dos pizarras para techar actualmente en explotación. La elevada eficacia de este producto se ha evaluado mediante la comparación del grado de oxidación de sulfuros en pizarras tratadas y no tratadas tras veinte ciclos térmicos, siendo el método que consigue una mayor eficacia el de inmersión completa de las planchas. El análogo solvente en agua, Tegosivin $\mathrm{HE}$, si bien muestra la misma eficacia, deja residuos visibles en la pizarra, lo que lo inhabilita, debido a este cambio de aspecto, para su aplicación en pizarras. El tiempo de contacto pizarra-producto, de is undoubtedly influenced by intrinsic parameters that determine reactivity to treatments, the product polymerization mechanism and, hence, ultimate effectiveness. It should be borne in mind that it is the static contact angle that is measured in our research and in the references cited above. According to some authors (21), it is more appropriate to use the decline angle, as using the contact angle may give rise to difficulties in interpreting the effectiveness of a treatment.

Nevertheless, the products are undeniably effective in terms of reducing water absorption capacity almost by half and slowing down oxidation during thermal cycles. The surface film that forms on the pyrrhotite inclusions seems to be sufficiently effective in protecting the slate from oxidation. Of the two silanes/siloxanes products evaluated, Tegosivin HL100 and Tegosivin HE328, the former appears to afford better protection against oxidation, whereas the latter leaves noticeable residues on the slabs. It now remains to pursue research in the area of defining an industrial application protocol, in which the key process will be the phase subsequent to immersion in terms of developing a procedure that will permit drying without prejudicing production speed.

In addition, another interesting study will be to test the effectiveness of other products designed to halt sulphide oxidation that have produced promising results in the laboratory $(11,12)$. These studies need to be conducted with the aim of adapting application to the industrial scale, which would require using commercially sized slabs of slate and evaluating not only the protective effects but also negative effects, particularly colour changes.

\section{CONCLUSIONS}

The results of this study support the conclusion that the commercial silane-siloxane Tegosivin HL can be used to slow down the oxidation rate of metal sulphides on two roofing slates currently in exploitation in Spain. The high efficacy of this product has been evaluated by comparing the degree of oxidation of sulphides in treated and untreated samples subjected to twenty thermal cycles; the great efficacy has been obtained applying the product by complete immersion of the plates. The analogue water solvent siloxane, Tegosivin $H E$, while displaying the same effectiveness, leave visible residues on the samples which disables it for industrial application due to this change in appearance, 
sólo medio minuto, permitiría su aplicación en planta sin comprometer la producción y salida al mercado.

Los resultados obtenidos de ángulo de contacto medidos sobre la pizarra tratada, que no superan los $90^{\circ}$ a pesar de la importante reducción mostrada tras el tratamiento de la capacidad de absorción de agua, invita a profundizar en el conocimiento de la interacción de estos productos, los siloxanos, tanto con la matriz filosilicatada como con los propios sulfuros. Sería interesante realizar medidas de ángulo de contacto dinámico (sobre todo teniendo en cuenta la características peculiares de estas rocas, principalmente en lo que se refiere a su distribución porosimétrica), aplicar distintas técnicas como la espectroscopia de infrarrojos por transformadas de Fourier $y$ la espectroscopia de fotoelectrones de rayos $X$ para conocer el grado de interacción entre los productos y los sulfuros así como ensayar otros productos, de eficacia probada en pirita en polvo, sobre planchas de tamaño comercial.

\section{AGRADECIMIENTOS}

Este trabajo ha sido financiado por el Ministerio de Educación y Ciencia a través del proyecto de investigación de referencia BIA2007-66218. Agradecemos a V. Cárdenes por su ayuda en el muestreo de las pizarras y a Evonik Industries su colaboración aportando los productos Tegosivin.
The time of application, only half a minute, would allow its application in plant without compromising the production and disposal of commercial slate.

The contact angle measurements of treated slates, which do not exceed $90^{\circ}$ despite the significant reduction after treatment of the water absorption capacity, invites a more in depth research on the interaction of these products, siloxanes, both with the phyllosilicated matrix and sulphides. It would be interesting to perform measurements of dynamic contact angle (especially taking into account the peculiar characteristics of these rocks, particularly in regard to porosimetric distribution), to apply different techniques such as Fourier Transformed Infrared Spectroscopy and $X$-Ray Photoelectron Spectroscopy to know the degree of interaction between the products and sulphides as well as to test other products, whose effectiveness has been proved in pyrite powder, on commercial-size roofing slates.

\section{ACKNOWLEDGEMENTS}

This research has been funded by the Spanish Ministry of Education and Science under research project BIA200766218. Our grateful thanks to $V$. Cárdenes for his contribution during the slate sampling and to Evonik Industries for their assistance in supplying the Tegosivin products.

\section{BIBLIOGRAFÍA / BIBLIOGRAPHY}

(1) Blanco, M.; Taboada Castro, J.; Martínez-Alegría López, R.: "Incidencia de las características mineralógicas y texturales en algunas propiedades de las pizarras de techar", Cuadernos del Laboratorio Xeolóxico de Laxe, vol. 14 (1989), pp. 247-254.

(2) García-Guinea, J.; Lombardero, M.; Roberts, B.; Taboada, J.; Peto, A.: "Mineralogía y microestructura de la pizarra de techar: comportamiento termoóptico y fisilidad", Mater. Construcc., vol. 48, no 251 (1998), pp. 37-48. doi:10.3989/mc.1998.v48.i251.470

(3) Cárdenes, V.; Lombardero, M.; García-Guinea, J.: "Factores de calidad en la elaboración de placas de pizarra para cubiertas en Galicia y León", Roc Máquina, vol. 67 (2001), pp. 90-98.

(4) García-Guinea, J.; Cárdenes, V.; Lombardero, M.: "Determination of iron sulphides in roofing slates from the north west of Spain", Mater. Construcc., vol. 52, no 266 (2002), pp. 55-63.

(5) Rimstidt, J. D.; Vaughan, D. J.: "Pyrite oxidation: a state of the art assessment of the reaction mechanism", Geochimica and Cosmochimica Acta, vol. 67, no 5 (2003), pp. 873-880. doi:10.1016/S0016-7037(02)01165-1

(6) Descostes, M.; Mercier, F.; Beaucaire, C.; Zuddas, P.; Trocellier, P.: "Nature and distribution of chemical species on oxidized pyrite surface: complementary of XPS and nuclear microprobe analysis", Nuclear Instruments and Methods in Physics Research B, vol. 181 (2001), pp. 603-609. doi:10.1016/S0168-583X(01)00627-9

(7) Descostes M.; Vitorge, P.; Beaucaire, C.: "Pyrite dissolution in acidic media", Geochimica et Cosmochimica Acta, vol. 68, n 22 (2004), pp. 4559-4569. doi:10.1016/j.gca.2004.04.012

(8) Evangelou V. P.: "Pyrite microencapsulation technologies: Principles and potential field application", Ecological Engineering, vol. 17 (2001), pp. 165-178. doi:10.1016/S0925-8574(00)00156-7

(9) Zhang, X.; Borda, M. J.; Schoonen, M. A. A.; Strogin, D. R.: "Pyrite oxidation inhibition by a corss-linked lípido coating", Geochem. Trans., vol. 4, no 2 (2003), pp. 8-11. doi:10.1186/1467-4866-4-8

(10) Kargbo, D. M.; Atallah, G.; Chatterjee, S.: "Inhibition of pyrite oxidation by a phospholipid in the presence of silicate", Environ. Sci. Technol, vol. 38 (2004), pp. 3432-3441. doi:10.1021/es0352552 
(11) Elsetinow, A. R.; Borda, M. J.; Schoonen, M. A. A.; Strongin D. R.: "Suppression of pyrite oxidation in acidic aqueous environments using lipids having two hydrophobic tails", Advances in Environmental Research, vol. 7 (2003), pp. 969-974. doi:10.1016/S10930191(02)00101-6

(12) Chen, Y. W.; Li, Y.; Cai, M. F.; Belzile, N.; Dang, Z.: "Preventing oxidation of iron sulphide minerals by polyethylene polyamines", Minerals Engineering, vol. 19 (2006), pp. 19-27. doi:10.1016/j.mineng.2005.04.007

(13) Lewin, S. Z.; Charola, A. E.: "Stone decay due to foreign inclusions", Proc. Int. Symp. The Conservation of Stone, Bologna (1981), R. Rossi Manaresi (ed.), vol. 2, pp. 205-217.

(14) Delgado, J.; Costa, D.; Ferreira, A. P.: "Assessment of the effectiveness and harmfulness of water repellents on granite", Proc. III Int. Symp. Conservation of Monuments in the Mediterranean Basin, Venice (1994), V. Fassina, H. Ortz and F. Zezza (eds.), pp. 883-890. (15) Rivas, T.; Silva, B.; Prieto, B.: "Medida de la eficacia de dos hidrofugantes aplicados a rocas graníticas", Mater. Construcc., vol. 48, no 249 (1998), pp. 5-21.

(16) Berardi, E.; Mecchi, A. M.; Calia, A., Lettieri, M.: "Water-repellent treatments on some calcareous Apulian stones of differing porosity", Proceedings of 5th International Symposium on the Conservation of Monuments in the Mediterranean basin, Seville, Spain (2002), pp. 401-406.

(17) Íñigo, A. C.; Vicente-Tavera, S.; Rives, V.: "Statistical design applied to hydric property behaviour for monitoring granite consolidation and/or water-repellency treatments", Mater. Construcc., vol. 56, no 281 (2006), pp. 19-30.

(18) De los Santos, D.; Rivas, T. B.; Prieto, P. Sanmartín: "Different behaviour of TEOS-based consolidant applied to granite and to biocalcareous sandstone", International Symposium on Stone Consolidation in Cultural Heritage-research and practice. Acces, research and Technology for the conservation of the European Cultural Heritage Eu-ARTECH (org.). Lisbon, 06/07/2008-07/07/2008.

(19) Álvarez de Buergo, M.; Fort González, R.: "Basic methodology for the assessment and selection of water-repellent treatments applied on carbonic materials", Progress in Organic Coatings, vol. 43 (2001), pp. 258-266. doi:10.1016/S0300-9440(01)00204-1

(20) Tsalakof, A.; Manoudis, P.; Karapanagiotis, I.; Chryssoulakis, I.; Panayiotou, C.: "Assesment of synthetic polymeric coatings fot the protection and preservation of stone monuments", Journal of Cultural Heritage, vol. 8 (2007), pp. 69-72. doi:10.1016/j.culher.2006.06.007 (21) Brugnara, M.; Degasperi, E.; Della Volpe, C.; Maniglio, D.; Penati, A.; Siboni, S.; Toniolo, L.; Poli, T.; Invernizzi, S.; Castelvero, V.: "The application of the contact angle in monuments protection: new materials and methods", Colloids and Surfaces A: Physicochem. Eng. Aspects, vol. 241 (2004), pp. 299-312. doi:10.1016/j.colsurfa.2004.04.035

(22) Julivert, M.; Fontbote, J. M.; Ribeiro, A.; Conde, L.: Mapa tectónico de la Península Ibérica y Baleares, IGME, Madrid (1972).

(23) Marcos, A.: "Las series del Paleozoico inferior y la estructura herciniana del occidente de Asturias (noroeste de España)", Trabajos de Geología de la Universidad de Oviedo, vol. 6 (1973), pp. 3-113.

(24) Pérez Estaun, A.: "Estratigrafía y estructura de la rama sur de la zona asturoccidental-leonesa", Memorias del IGME, vol. 92 (1978), Madrid.

(25) Barros, J. C.: "Nuevos datos geológicos y cartográficos sobre el flanco sur del Sinclinorio de Truchas", Cuadernos do Laboratorio Xeolóxico de Laxe, vol. 14 (1989), pp. 93-116.

(26) European Committee for Standardization, EN 12326-2 European Standard: Slate and stone products for discontinuous roofing and cladding, part. 2: Test Methods (2000).

(27) International Commission on Illumination, CIE S 014-4/E: 2007 Colorimetry-part 4: CIE 1976 L*a*b* Colour Space, CIE Central Bureau, Vienna (2007). 